\title{
Root Morphology and Anatomy of Field-Grown Erianthus arundinaceus
}

\author{
Fumitaka Shiotsu ${ }^{1}$, Jun Abe ${ }^{2 *}$, Tetsuya Doi $^{3}$, Mitsuru Gau ${ }^{4}$, Shigenori Morita ${ }^{5}$ \\ ${ }^{1}$ College of Agriculture, Ibaraki University, Ibaraki, Japan \\ ${ }^{2}$ Department of Plant Science, School of Agriculture, Tokai University, Kumamoto, Japan \\ ${ }^{3}$ Institute for Sustainable Agro-Ecosystem Services (ISAS), Graduate School of Agricultural and Life Sciences, \\ The University of Tokyo, Tokyo, Japan \\ ${ }^{4}$ National Agricultural Research Center for Kyushu Okinawa Region, National Agricultural Research \\ Organization (NARO), Kumamoto, Japan \\ ${ }^{5}$ Department of Agriculture, Faculty of Agriculture, Tokyo University of Agriculture, Kanagawa, Japan \\ Email: ${ }^{*}$ abejun@agri.u-tokai.ac.jp
}

Received 15 December 2014; accepted 29 December 2014; published 13 January 2015

Copyright (C) 2015 by authors and Scientific Research Publishing Inc.

This work is licensed under the Creative Commons Attribution International License (CC BY).

http://creativecommons.org/licenses/by/4.0/

(c) (i) Open Access

\section{Abstract}

Erianthus species are perennial C4 grasses with such high biomass productivity and high tolerance to environmental stresses that they can be grown in marginal land to supply raw material for cellulosic bioethanol. Because high biomass production and strong tolerance to environmental stresses might be based on their large and deep-root system, we closely examined the morphology and anatomy of roots in first-year seedlings of field-grown Erianthus arundinaceus. The deep-root system of $E$. arundinaceus consists of many nodal roots growing with steep growth angles. Diameter of nodal roots with large variations $(0.5-5 \mathrm{~mm})$ correlates with the size and number of large xylem vessels. The microscopic observation shows that the nodal roots with dense root hairs developed soil sheath, hypodermis with lignified sclerenchyma in the outer cortex, and aerenchyma in the mid-cortex. In addition, starch grains were densely accumulated in the stele of nodal roots in winter. In the first year, E. arundinaceus developed less lateral roots than other reported grass species. The lateral roots formed a large xylem vessel in the center of the stele and no hypodermis in the outer cortex. Morphology and anatomy of $E$. arundinaceus root were discussed with reference to strong tolerance to environmental stresses.

\section{Keywords}

Erianthus arundinaceus, Root Diameter, Sclerenchyma, Soil Sheath, Starch Grain, Xylem Vessel

${ }^{*}$ Corresponding author. 


\section{Introduction}

Energy consumption in the world based mainly on fossil energy has doubled in the 20th century, which has raised the concentration of carbon dioxide in the atmosphere. Reducing dependence on petroleum is, therefore, essential for combating global warming [1]-[3]. Bioethanol produced from plant biomass is a renewable and alternative fuel that can be a countermeasure to global warming when produced in appropriate ways [4] [5]. Rapid increase of bioethanol production from cereal crops in the world [6], on the other hand, may cause possible competition for cereal crops between food and bioethanol [7] [8]. Non-edible cellulosic energy crops (e.g. switchgrass, napier grass, Erianthus spp. and Miscanthus spp.), therefore, are expected to be grown on degraded lands as raw material crops for bioethanol instead of edible energy crops (e.g. sugar cane, maize and cassava) [3] [9]-[14].

Erianthus species which have been used as genetic resources for breeding sugarcane [15]-[18] and as potential forage crops [16] [19] might be potential raw crops for bioethanol [11] [12] [20], because they have huge biomass as well as high tolerance to biotic and abiotic stresses, such as drought, waterlogging, and soil hardness. Although morphological and anatomical characteristics of roots have possible relation to tolerance of the plant to such environmental stresses [21]-[31], there has been quite limited information on their roots. In this study, morphology and anatomy of roots in a promising strain, KO-1 of E. arundinaceus originated from Tanegashima Island $\left(30^{\circ} \mathrm{N}, 130^{\circ} \mathrm{E}\right)$ in a subtropical area of Japan to discuss their possible contribution to the high productivity and strong tolerance to soil-related stresses.

\section{Material and Methods}

Five-month-old seedlings of E. arundinaceus (strain KO-1; [32]) grown in a greenhouse at the National Agricultural Research Center for Kyushu Okinawa Region (Kumamoto, Japan) were transplanted at planting density of four plants per $\mathrm{m}^{2}(0.5 \mathrm{~m} \times 0.5 \mathrm{~m}$ spacing $)$ in a field of the Institute for Sustainable Agro-ecosystem Services, The University of Tokyo $\left(35^{\circ} 43^{\prime} \mathrm{N}, 139^{\circ} 32^{\prime} \mathrm{E}\right.$; Nishitokyo, Japan) on July 29, 2009. Before planting the field of humic Andosol was fertilized at rate of $\mathrm{N}: 100, \mathrm{P}_{2} \mathrm{O}_{5}: 150, \mathrm{~K}_{2} \mathrm{O}: 130 \mathrm{~kg} \cdot \mathrm{ha}^{-1}$ before planting.

Plant height and stem number of 12 selected plants were recorded every two weeks. Roots were taken by monolith method [33] [34] at 80 and 141 days after planting (DAP). In addition, five soil cores (5 cm in diameter $\times 0.6 \mathrm{~m}$ deep) were collected from locations adjacent to Erianthus plants and in interrows using the DIK110B liner sampler (Daiki Rika Kogyo Co., Ltd.). Soil monoliths and soil cores were divided by 15 or $30 \mathrm{~cm}$ increments to wash roots out carefully. The number of nodal roots from the plants collected by the monolith method was counted. Images of roots were scanned at 200 dpi using the image scanner (Epson Expression $10000 \mathrm{XL}$ ) to measure root length including laterals as a function of root diameter using WinRHIZO Regular (Regent Instruments Inc.). Thereafter the roots were dried at $80^{\circ} \mathrm{C}$ for three days to weigh, and specific root length (ratio of total root length to total dry weight) was calculated.

In addition, Erianthus plants with roots were taken out using a shovel at 148 DAP (December 24, 2009). Diameters of randomly selected nodal roots of a dozen were measured using a digital caliper at $\mathrm{ca} .5 \mathrm{~cm}$ from their base. Twenty-one additional nodal roots were randomly chosen for anatomical observation. Freehand cross sections of these fresh roots were observed using a light microscope (BX-60, Olympus Corp.) to record the diameters of root, stele and large xylem vessels, the pole numbers (i.e., number of protoxylem) and large xylem vessels. Equivalent diameter of large xylem vessels was calculated as the biquadratic root of sum of the fourth power of the large xylem vessel $\left.[\Sigma \text { (diameter of large xylem vessels) })^{4}\right]^{1 / 4}$ on the basis of the Hagen-Poiseuille equation [35]. Some of the cross sections of nodal roots were stained with phloroglucinol-HCl [36] and potassium iodide solutions [37] to detect lignin and starch, respectively. Furthermore, cross sections of several lateral roots were observed microscopically to measure thickness and stele diameter. Erianthus plants with roots were again harvested in summer using a shovel (349 DAP; July 13, 2010) to observe starch accumulation in nodal roots.

\section{Results}

\subsection{Plant Growth}

Plant height and stem number increased until autumn of 2009 (85 DAP) and the plant leveled off in winter. Shoot dry weight, however, increased by 1.7-fold (80 DAP - 141 DAP) during winter (Table 1). The number 
Table 1. Characteristics of Erianthus shoots at different growth stages (80 and 141 days after planting [DAP]).

\begin{tabular}{ccc}
\hline Shoot characteristics & 80 DAP & 141 DAP \\
\hline Plant height (cm) & $121 \pm 4.2$ & $121 \pm 6.1$ \\
Stem number (per plant) & $44 \pm 11.6$ & $47 \pm 12.8$ \\
Shoot dry weight (g per plant) & $66 \pm 7.1$ & $112 \pm 18.2$ \\
\hline
\end{tabular}

The values indicate means and standard errors for 12 plants.

of nodal roots was almost constant throughout the growing period (ca. 70, Table 2). Most nodal roots emerged from relatively thick stems to grow downwards (Figure 1(a)), while many small tillers lacked nodal ones.

\subsection{Root Diameter and Branching Index}

Diameter of nodal roots at 148 DAP widely varied (Figure 1(b)), ranging from 0.5 to $5 \mathrm{~mm}$ (from 1 to 3 mm even among young nodal roots less than $10 \mathrm{~cm}$ ). Figure 2 shows the distribution of root length as a function of their diameter at 80 DAP (including lateral roots). Considering the root diameter from both WinRHIZO measurement (see above) and microscopic observation (see the next section), we recognized roots of less than 0.5 mm diameter as lateral ones. The branching index (i.e., [total length of lateral roots]/[total length of nodal root axes]; [38]) was 2.8 and 1.9 in $0-15 \mathrm{~cm}$ and $15-30 \mathrm{~cm}$ soil layer, respectively. The branching indices of roots collected by the core sampling method at $0-15 \mathrm{~cm}, 15-30 \mathrm{~cm}$, and $30-60 \mathrm{~cm}$ soil layers were $5.6,2.4$, and 3.3 , respectively. The specific root length (i.e., root length per unit root weight) was $7.4 \mathrm{~m} \cdot \mathrm{g}^{-1}$ at 80 DAP decreasing to $4.4 \mathrm{~m} \cdot \mathrm{g}^{-1}$ at $141 \mathrm{DAP}$ (Table 2).

\subsection{Anatomy of Nodal Roots}

Nodal roots were tightly covered with the soil sheath [28] [39] adhering to the root epidermis (Figure 3(a), Figure 3(b)) with dense root hairs (Figure 3(a), Figure 3(c)).

Outermost 2 through 4 cell layers of the cortex was hypodermis (Figure 3(c), Figure 3(d)). Hypodermal cells in the cell layer below epidermis were similar in size to epidermal ones, whereas the second layer of the hypodermis consisted of smaller sclerenchyma cells (Figure 3(d)). The sclerenchyma with lignified cell walls was partly double layered or multiseriate (Figure 3(d)). Most nodal roots formed well-developed aerenchyma in the mid-cortex (Figure 3(b), Figure 3(e)). Endodermal cells had thick inner tangential cell walls heavily lignified, and sometimes showed periclinal division (Figure 3(f)).

The stele (central cylinder) consisted of three parts: a marginal cylinder of multiseriate lignified pericycle, a ring of conducting tissues, and parenchymatous central pith (Figure 3(b)). Pericycle is not easily idendified and it is composed of 2 - 4 layers of oval cells with thick and heavily-lignified walls, which is different from other cereal crops (Figure 3(f)). Xylem and phloem poles were located in a circle at regular intervals in the outer parts of the stele, and large xylem vessels were inside (Figure 3(b), Figure 3(f)). The small and large xylem could be protoxylem and metaxylem, respectively, according to their size and position. The center of the stele is occupied by unlignified parenchymatous cells with starch grains stained with potassium iodide (Figure 3(g)) at 148 DAP (December, 2009). Some roots had such starch grains even in oval cells in the lignified marginal cylinder of multiseriate pericycle. Almost no starch grains, in contrast, were observed in the stele of Erianthus roots harvested in summer (349 DAP), except in a few aged roots (Figure 3(h)).

The relationships between root diameter, stele size, and number of xylem poles were analyzed for the 21 nodal roots. Stele diameter was closely correlated to root diameter (Table 3, Figure 4(a)). Moreover, the number of xylem poles and large xylem vessels (Figure 4(b)) and mean diameter of large xylem vessels (Figure 4(c)) were positively correlated with root diameter (Table 3). The equivalent diameter of the xylem vessels, therefore, could be estimated from the root diameter (Figure 4(d)).

\subsection{Anatomy of Lateral Roots}

Lateral roots have neither lignified hypodermis or aerenchyma as in the cortex of nodal roots, while the endodermis with thickened inner tangential cell walls was developed (Figure 3(i)). There was one large xylem vessel in the center of the stele where no starch grain was accumulated. The ratio of stele diameter to root diameter in 
Table 2. Characteristics of Erianthus roots collected by the monolith method at different growth stages (80 and 141 days after planting [DAP]).

\begin{tabular}{ccc}
\hline Root characteristics & 80 DAP & 141 DAP \\
\hline Root Number (per plant) & $74 \pm 8.6$ & $69 \pm 5.2$ \\
Root dry weight (g per monolith) & $8.41 \pm 1.17$ & $15.95 \pm 2.48$ \\
Root dry weight (g per plant) & $140 \pm 19.4$ & $265 \pm 41.4$ \\
Root weight density (mg. $\mathrm{cm}^{-3}$ ) & $0.93 \pm 0.13 \pm 0.28$ \\
Root length (m per plant) & $1000 \pm 136$ & $1098 \pm 27$ \\
Root length density $\left(\mathrm{cm} \cdot \mathrm{cm}^{-3}\right.$ ) & 1.3 & 1.5 \\
Specific root length $\left(\mathrm{m} \cdot \mathrm{g}^{-1}\right.$ ) & 7.4 & 4.4 \\
\hline
\end{tabular}

The values indicate means and standard errors of four monoliths. Root density and specific root length were calculated using the mean values of root length and dry weight.

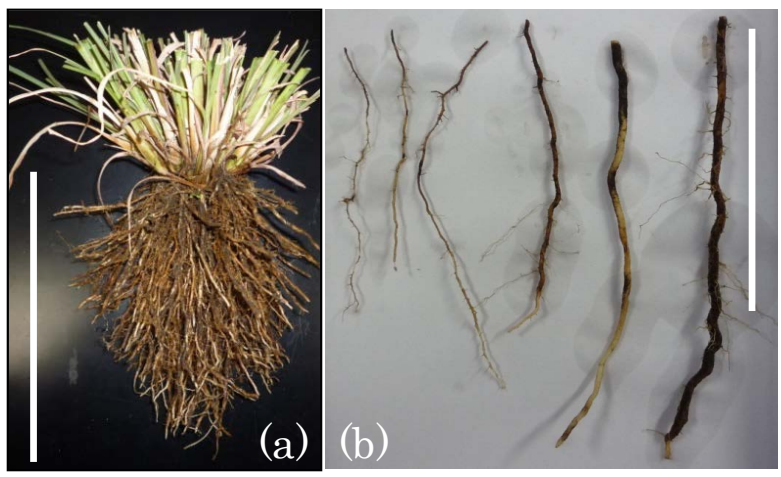

Figure 1. Erianthus root systems (a) and individual nodal roots with laterals (b) at 148 days after planting. Scale bars indicate $30 \mathrm{~cm}$ (a) and $10 \mathrm{~cm}(\mathrm{~b})$.

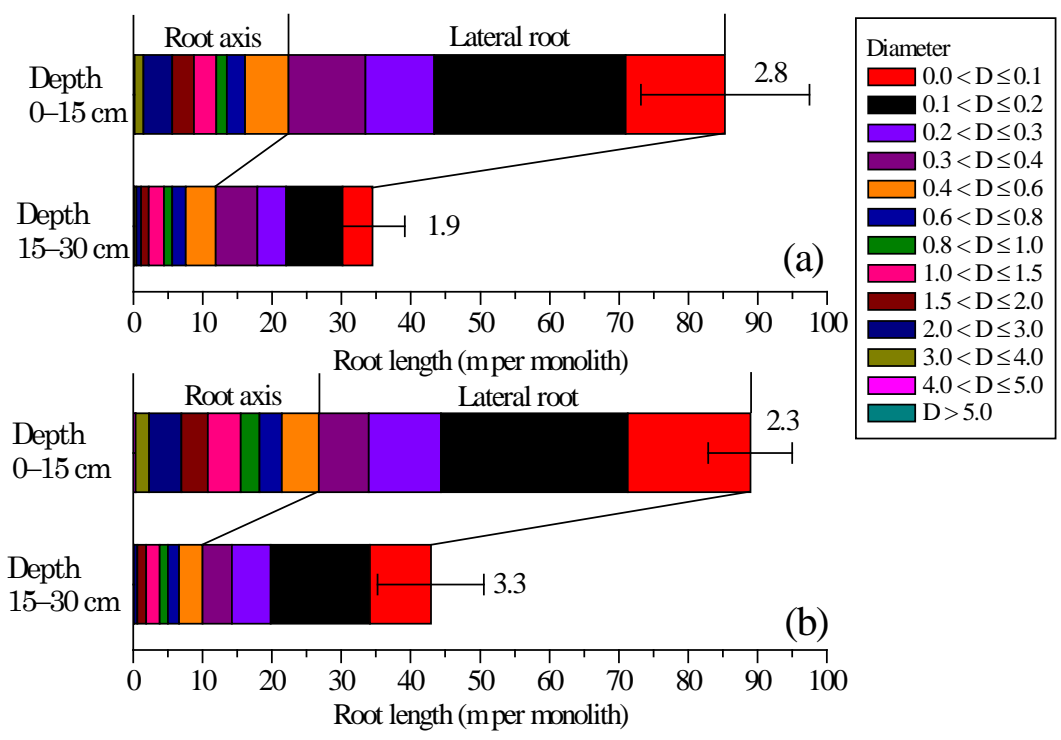

Figure 2. Distribution of root length as a function of their diameters; the roots were collected by the monolith method at 80 (a) and 141 days (b) after planting. The numbers on the right of individual bars indicate the branching index. The error bar indicates standard error of total root length. 

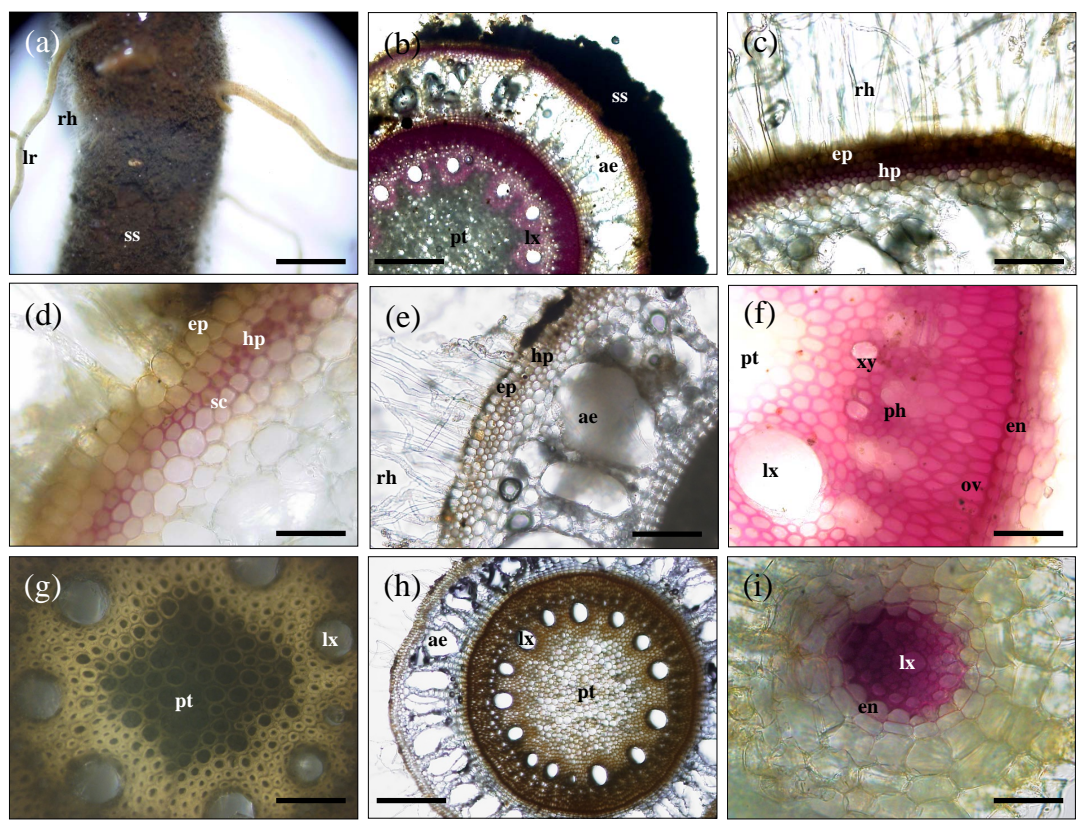

Figure 3. Anatomy of a Erianthus nodal (a)-(h) and lateral roots (i). Freehand cross-sections of nodal roots were taken at $5 \mathrm{~cm}$ from the base of the roots. The red color of the cell wall indicates lignifications detected by phloroglucinol staining (b), (c) (d) (f) and (i). Potassium iodide staining ( $\mathrm{g}$ and $\mathrm{h}$ ) detected starch in the stele of only Erianthus nodal roots in winter; the starch was stained black (g). Erianthus roots harvested in summer (h) had no starch in the stele. ae, aerenchyma in the mid-cortex; en, endodermis; ep, epidermis; hp, hypodermis; lx, large xylem vessels; lr, lateral root; ov, oval cell; ph, phloem; pt, parenchymatous cells in the stele; rh, root hair; sc, sclerenchyma; ss, soil sheath; and xy, small xylem vessel. The scale bars indicate $2 \mathrm{~mm}$ (a), 500 $\mu \mathrm{m}(\mathrm{b})$ and (h), $200 \mu \mathrm{m}$ (c) and (e) and $100 \mu \mathrm{m}$ (d) (f) and (g).
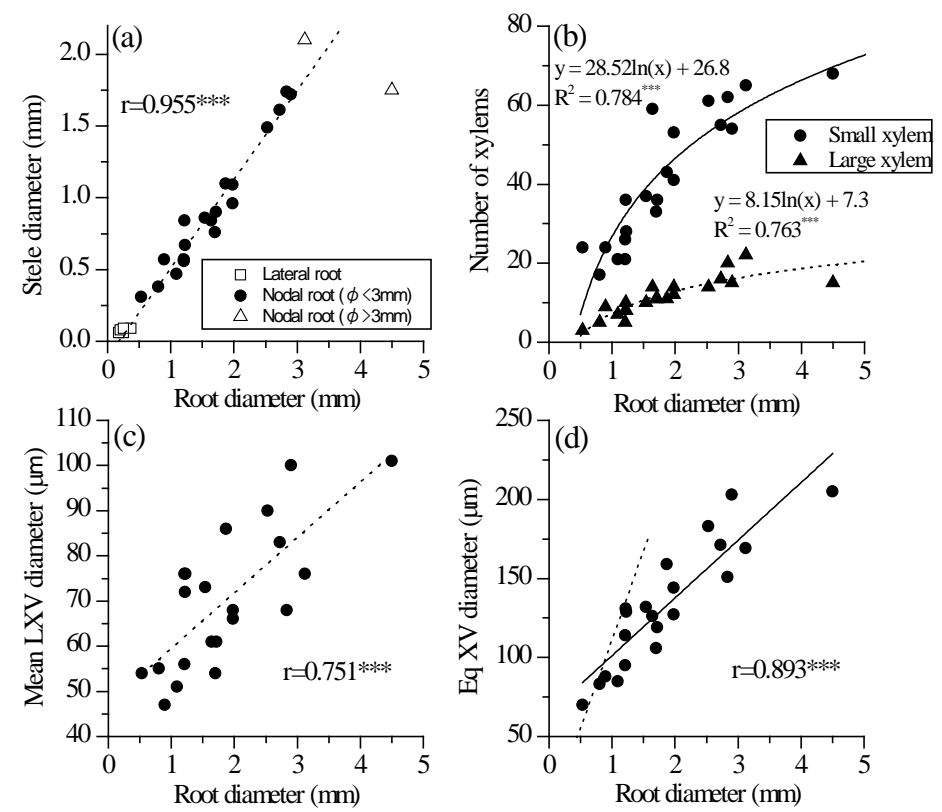

Figure 4. Relationship between root diameter and stele anatomical properties at $5 \mathrm{~cm}$ from the base of the nodal root. (a) Stele diameter; (b) Numbers of xylem poles (small xylem points) and large xylem vessels; (c) Mean diameter of large xylem vessels (LXV); and (d) Equivalent diameter of xylem vessels (XV). Linear regression line and correlation efficiency in (a) were calculated for nodal roots thinner than $3 \mathrm{~mm}$. *** indicate significant correlation at $p<0.001$. 
Table 3. Correlation efficiencies of root diameter and stele properties at $5 \mathrm{~cm}$ from the base of nodal roots.

\begin{tabular}{|c|c|c|c|c|c|c|}
\hline & Root Diameter & Stele Diameter & No. of PN & No. of LXV & $\begin{array}{c}\text { Mean LXV } \\
\text { diameter }\end{array}$ & $\Sigma(\mathrm{LXV}$ area $)$ \\
\hline Stele Diameter & $0.920 * * *$ & & & & & \\
\hline No. of PN & $0.878 * * *$ & $0.907 * * *$ & & & & \\
\hline No. of LXV & $0.814^{* * *}$ & $0.927 * * *$ & $0.909^{* * *}$ & & & \\
\hline Mean LXV diameter & $0.751^{* * *}$ & $0.720 * * *$ & $0.648^{* *}$ & $0.472^{*}$ & & \\
\hline$\Sigma(\mathrm{LXV}$ area $)$ & $0.933^{* * *}$ & $0.949 * * *$ & $0.884^{* * *}$ & $0.804^{* * *}$ & $0.869 * * *$ & \\
\hline Eq XV diameter & $0.893 * * *$ & $0.900^{* * *}$ & $0.858 * * *$ & $0.754 * * *$ & $0.925^{* * *}$ & $0.974 * * *$ \\
\hline
\end{tabular}

Correlation efficiencies were calculated on the basis of data acquired from 21 nodal roots (d.f. $=19$ ). *, **, and *** indicate significant correlation at $p<0.05, p<0.01$, and $p<0.001$, respectively. PN, pole number; LXV, large xylem vessel; No., number; $\Sigma(\mathrm{LXV}$ area), total cross-sectional area of large xylem vessel elements; Eq XV diameter, equivalent xylem vessel diameter.

lateral roots was similar to that in nodal roots (open squares in Figure 4(a)).

\section{Discussion}

Preliminary observation on three-year-old Erianthus (same strain KO-1) showed that their root system has at least $2.6 \mathrm{~m}$ depth and nearly $20 \%$ of roots distributed deeper than $1.5 \mathrm{~m}$ [40]. Root distribution in the fibrous root system of grasses is determined by a combination of factors such as root growth direction [41] [42], root length [43] [44], and root penetrating ability into hard soil [45] [46]. It has already known that thick nodal roots of cereal crops, in general, tend to elongate vertically [41] [42] [47]. In the present study, the first-year plants of E. arundinaceus possessed many thick roots with diameter over 2 mm even at the early growth stage (Figure 2, Figure 4), and most nodal roots mainly elongated vertically (Figure 1(a)). Plant species and genotype with such thick nodal roots also have advantage to penetrate into deeper soil layer [48] [49]. Matsuo et al. [16] suggested that the roots of Thailand strain of Erianthus have high ability to penetrate hardpan based on their field study in Northeast Thailand. Such morphological traits of Erianthus roots could lead to develop deep root system, which has advantage to environmental stresses for example drought by extracting soil water remaining in deep soil layer.

Nodal roots of Erianthus was characterized by small specific root length in the present study, which suggests larger diameter and less branching of nodal roots in the first year (Table 2, Figure 2). Thick nodal roots of E. arundinaceus have numerous large xylem vessels with linified cell walls which are adaptive to support huge aboveground part as reported in maize [50]. Less branching was confirmed by lower branching index (1.9 - 5.6) compared with cereal crops such as wheat (3 - 10 in nodal roots about 145 days after sowing; [51]), or maize (10 - 150 in mature nodal roots ca. 120 days after sowing; [52]). High specific root length and low branching index of E. arundinaceus roots suggests advantage in nodal root development rather than lateral root formation at early growth stages in Erianthus (Table 2). Our preliminary observation on three-year-old Erianthus, however, showed the development of shallow nodal roots with numerous lateral roots (data not shown) as well as deep nodal roots. Root system development could also change with growth stages in other cereal crops [51] [53] [54]. Root system development in younger Erianthus could be characterized by thick and deep nodal roots with less branching as the "buttress roots" in sugarcane; and older Erianthus may develop “superficial roots”.

Equivalent xylem vessel diameter defined as a function of the fourth power of mainly large xylem vessel diameter (see Material and Methods) is thought as an index of total conductivity in roots having xylem vessel with different number and size [35] [55]. The amount of vascular tissues often correlates to the root or stele diameter [55]-[58] as was confirmed in Erianthus roots in this study (Table 3, Figure 4(b), Figure 4(c)). Equivalent xylem vessel diameter has linear relationship to root or stele diameter (Figure 4(d)), which suggests Erianthus root system could have higher water conductivity based on thicker and larger nodal roots comparing with other cereal crops. Vessel anatomy also suggests that Erianthus root system has high potential in absorption and transportation of water. Although lateral roots were much thinner than nodal roots, the ratio of stele diameter to root diameter was almost the same in both (Figure 4(a)), suggesting that diameter of roots may determine their conductivity in both nodal and lateral roots. 
E. arundinaceus roots also have another morphological and anatomical traits adaptive for environmental stresses. The nodal roots, for example, have soil sheaths (Figure 3(a), Figure 3(b)) as in maize [39] [59]. Dense root hairs of $E$. arundinaceus were observed in the soil sheath (Figure 3(a)), suggesting the involvement of root hairs with mucilage in the development of the soil sheath. Here we found that most parts along the root axis of $E$. arundinaceus nodal roots, including the mature parts, were tightly surrounded by the soil sheath, which may protect and help roots to absorb water and nutrients even in drought [28] [60].

The outer cortex of E. arundinaceus roots developed the hypodermis (Figure 3(c), Figure 3(d)). The hypodermis of grass roots can protect inner tissues including vascular systems from external biotic and abiotic stresses [26] [61]. The hypodermis in the Erianthus root included partly multiseriate sclerenchyma with lignified cell walls as in rice roots [62] [63] and other cereals crops (e.g., pearl millet; [64]). The degree of sclerenchyma development can correspond to the drought tolerance ability of the plant. For example, several upland rice varieties with high drought tolerance form multiseriate sclerenchyma, whereas most lowland and many of drought-sensitive upland rice varieties possess single-layered sclerenchyma [65]. Drought-tolerant sorghum cultivars develop thick sclerenchyma cell walls in contrast to drought-sensitive cultivars [29]. Therefore, the formation of multiseriate and well-lignified sclerencyma in Erianthus roots may also contribute to high tolerance to environmental stress. Lateral roots of Erianthus, on the other hand, had no hypodermis (Figure 3(i)), which suggests their high permeability to water and nutrients in comparison with their parental nodal roots.

Matsuo et al. [16] already reported the formation of aerenchyma in the root cortex of submerged Erianthus in Thailand. Such aerenchyma was well developed in most nodal roots of E. arundinaceus thougheven in the not-submerged plants in this study (Figure 3(b), Figure 3(e)). This fact suggests that Erianthus may have adapted to tropical and subtropical monsoon climates where wet and dry conditions occur periodically.

Additionally, stele of Erianthus roots was characterized by multiseriate pericycle and accumulation of starch grains (Figure 3(f)-(g)). The lignified marginal cylinder of multiseriate pericycle with oval cells in stele is quite different from the single-layer pericycle of cereal crops (Figure 3(f)), but Raechal and Curtis [66] found sclerified multiseriate pericycles in some of Bambusoideae species. The starch grains accumulated could disappear in next summer. Yamashita and Okamoto [67] reported that numerous starch grains accumulated around secondary xylem of roots of mountain azalea (Rhododerndron Kurume group) in winter (December-February) and disappeared in summer (June-August). In Erianthus, adventitious lateral root are rarely formed, but the starch stock in roots may be advantageous for vigorous root activity under cold conditions in winter. Moreover, starch storage in winter may contribute to shoot regrowth in spring.

\section{Concluding Remarks}

Erianthus is one of the possible candidates for raw material crop for lignocellulosic bioethanol, because it has vigorous biomass production and high tolerance to environmental stresses. One of the reasons why Erianthus species have high performance is probably related to root system development. Large and deep root system has advantage for dry and poor soil conditions. Several anatomical traits including development of soil sheath including dense root hairs, hypodermis, aerenchyma, vascular system and starch grain accumulation characteristic in Erianthus could also be adaptive environmental stresses.

\section{Acknowledgements}

The present research is supported by the New Energy and Industrial Technology Development Organization with a grant for "Research and Development for Innovative Production System of Cellulosic Ethanol (Research and Development of an Integrated System for Bioethanol Production)", and also by The New Technology Development Foundation. We thank Mr. S. Hatano, Mr. S. Kamikawa, Mr. H. Teshima (technical staff of the Institute for Sustainable Agro-ecosystem Services, The University of Tokyo) for their technical assistance in conducting experiments.

\section{References}

[1] Houghton, J. (2005) Global Warming. Reports on Progress in Physics, 68, 1343-1403. http://dx.http://dx.doi.org/.org/10.1088/0034-4885/68/6/R02 
[2] Nakićenović, N., Grübler, A., Inaba, A., Messner, S., Nilsson, S., Nishimura, Y., Rogner, H.H., Schäfer, A., Schrattenholzer, L., Strubegger, M., Swisher, J., Victor, D. and Wilson, D. (2003) Long-Term Strategies for Mitigating Global Warming. Energy, 18, 401-409. http://dx.http://dx.doi.org/.org/ 10.1016/0360-5442(93)90019-A

[3] Tilman, D., Socolow, R., Foley, J.A., Hill, J., Larson, E., Lynd, L., Pacala, S., Reilly, J., Searchinger, T., Somerville, C. and Williams, R. (2009) Beneficial Biofuels-The Food, Energy, and Environment Trilemma. Science, 325, 270-271. http://dx.http://dx.doi.org/.org/10.1126/science.1177970

[4] Börjesson, P. (2009) Good or Badbioethanol from a Greenhouse Gas Perspective-What Determines This? Applied Energy, 86, 589-594. http://dx.doi.org/10.1016/j.apenergy.2008.11.025

[5] Lynd, L.R., Cushman, J.H., Nichols, R.J. and Wyman, C.E. (1991) Fuel Ethanol from Cellulosic Biomass. Science, 251, 1318-1323. http://dx.doi.org/10.1126/science.251.4999.1318

[6] Licht, F.O. (2007) World Ethanol and Biofuels Report, 354.

[7] Harvey, M. and Pilgrim, S. (2011) The New Competition for Land: Food, Energy, and Climate Change. Food Policy, 36(S1), 40-51. http://dx.doi.org/10.1016/j.foodpol.2010.11.009

[8] Rathmann, R., Szklo, A. and Schaeffer, R. (2010) Land Use Competition for Production of Food and Liquid Biofuels: An Analysis of the Arguments in the Current Debate Review Article. Renewable Energy, 35, 14-22. http://dx.doi.org/10.1016/j.renene.2009.02.025

[9] Hattori, T. and Morita, S. (2010) Energy Crops for Sustainable Bioethanol Production Which, Where and How? Plant Production Science, 13, 221-234. http://dx.doi.org/10.1626/pps.13.221

[10] Hill, J., Nelson, E., Tilman, D., Polasky, S. and Tiffany, D. (2006) Environmental, Economic, and Energetic Costs and Benefits of Biodiesel and Ethanol Biofuels. Proceedings of the National Academy of Sciences of the United States of America, 103, 11206-11210. http://dx.doi.org/10.1073/pnas.0604600103

[11] Matsumoto, N., Sano, D. and Elder, M. (2009) Biofuel Initiatives in Japan: Strategies, Policies, and Future Potential. Applied Energy, 86, S69-S76. http://dx.doi.org/10.1016/j.apenergy.2009.04.040

[12] Nakagawa, H. (2009) Characteristics of Tropical Grasses for Biomass Production and the Breeding for Biofuel Feedstockes. Japanese Journal of Grassland Science, 55, 274-283.

[13] Sivakumar, G., Vail, D.R., Xu, J., Burner, D.M., Lay Jr., J.O., Ge, X. and Weathers, P.J. (2010) Bioethanol and Biodiesel: Alternative Liquid Fuels for Future Generations. Engineering in Life Sciences, 10, 8-18. http://dx.doi.org/10.1002/elsc.200900061

[14] Yuan, J.S., Tiller, K.H., Al-Ahmad, H., Stewart, N.R. and Stewart Jr., C.N. (2008) Plants to Power: Bioenergy to Fuel the Future. Trends in Plant Science, 13, 421-429. http://dx.doi.org/10.1016/j.tplants.2008.06.001

[15] Aitken, K., Li, J., Wang, L., Qing, C., Fan, Y.H. and Jackson, P. (2007) Characterization of Intergenetic Hybrids of Erianthus rockii and Saccharum Using Molecular Markers. Genetic Resources and Crop Evolution, 54, 1395-1405. http://dx.doi.org/10.1007/s10722-006-9124-2

[16] Matsuo, K., Chuenpreecha, T., Matsumoto, N. and Ponragdee, W. (2002) Eco-Physiological Characteristics of Erianthus spp. and Yielding Abilities of Three Forages under Conditions of Cattle Feces Application. JIRCAS Working Report, 30, 187-197.

[17] Ram, B., Sreennivasan, T.V., Sahi, B.K. and Singh, N. (2001) Introgression of Low Temperature and Red Rot Resistance from Erianthus in Sugarcane. Euphytica, 122, 145-153. http://dx.doi.org/10.1023/A:1012626805467

[18] Sugimoto, A., Ponragdee, W., Sansayawichai, T., Kawashima, T., Thippayarugs, S., Suriyaphan, P., Matsuoka, M., Lerdprasertrat, K. and Pramanee, P. (2002) Collecting and Evaluating of Wild Relatives of Sugarcane as Breeding Materials of New Type Sugarcane Cultivars of Cattle Feed in Northeast Thailand. JIRCAS Working Report, 30, 55-60.

[19] Gau, M., Goto, K., Katsura, M. and Matsuoka, H. (2004) Genetic Resources for High-Yielding Forage in Tropical Grass. Japanese Journal of Grassland Science, 50, 324-325.

[20] Mislevy, P., Martin, F.G., Adjei, M.B. and Miller, J.D. (1997) Harvest Management Effects on Quantity and Quality of Erianthus Plant Morphological Components. Biomass and Bioenergy, 13, 51-58. http://dx.doi.org/10.1016/S0961-9534(97)00023-8

[21] Chaves, M.M., Maroco, J.P. and Pereira, J.S. (2003) Understanding Plant Responses to Drought-From Genes to the Whole Plant. Functional Plant Biology, 30, 239-264. http://dx.doi.org/10.1071/FP02076

[22] De Kroon, H. and Visser, E.J.W. (2003) Root Ecology. Spinger-Verlag, Berlin Heidelberg.

[23] Gewin, V. (2010) Food: An Underground Revolution. Nature, 466, 552-553. http://dx.doi.org/10.1038/466552a

[24] Hodge, A., Berta, G., Doussan, C., Merchan, F. and Crespi, M. (2009) Plant Root Growth, Architecture and Function. Plant and Soil, 321, 153-187. http://dx.doi.org/10.1007/s11104-009-9929-9

[25] Ješko, T., Navara, J. and Dekánková, K. (1997) Root Growth and Water Uptake by Flowering Maize Plants, under 
Drought Conditions. In: Altman, A. and Waisel, Y., Eds., Biology of Root Formation and Development, Plenum Press, New York, 270-271. http://dx.doi.org/10.1007/978-1-4615-5403-5_53

[26] Lux, A., Luxová, M., Abe, J. and Morita, S. (2004) Root Cortex: Structural and Function Variability and Responses to Environmental Stress. Root Research, 13, 117-131. http://dx.doi.org/:10.3117/rootres.13.117

[27] Lynch, J. (1995) Root Architecture and Plant Productivity. Plant Physiology, 109, 7-13.

[28] McCully, M.E. (1999) Roots in Soil: Unearthing the Complexities of Roots and Their Rhizospheres. Annual Review of Plant Physiology and Plant Molecular Biology, 50, 695-718. http://dx.doi.org/10.1146/annurev.arplant.50.1.695

[29] Salih, A.A., Ali, I.A., Lux, A., Lxxová, M., Cohen, Y., Sugimoto, Y. and Inanaga, S. (1999) Rooting, Water Uptake, and Xylem Structure Adaption to Drought of Two Sorghum Cultivars. Crop Science, 39, 168-173. http://dx.doi.org/10.2135/cropsci1999.0011183X003900010027x

[30] Kato, Y., Abe, J., Kamoshita, A. and Yamagishi, J. (2006) Genotypic Variation in Root Growth Angle in Rice (Oryza sativa L.) and Its Association with Deep Root Development in Upland Fields with Different Water Regimes. Plant and Soil, 287, 117-129. http://dx.doi.org/10.1007/s11104-006-9008-4

[31] Kramer, P.J. and Boyer, J.S. (1995) Water Relations of Plants and Soils. Academic Press, San Diego.

[32] Uwatoko, M., Tanaka, M., Saito, A. and Gau, M. (2011) Establishment of Plant Regeneration System in Erianthus arundinaceus (Retz.) Jeswiet, a Potential Biomass Crop. Grassland Science, 57, 231-237. http://dx.doi.org/10.1111/j.1744-697X.2011.00234.x

[33] Böhm, W. (1979) Method of Studying Root Systems. Springer-Verlag, Berlin Heidelberg, New York.

[34] Oyanagi, A., Nakamoto, T. and Wada, M. (1993) Relationship between Root Growth Angle of Seedlings and Vertical Distribution of Roots in the Field in Wheat Cultivars. Japanese Journal of Crop Science, 62, 565-570. http://dx.doi.org/10.1626/jcs.62.565

[35] Zimmerman, M.H. (1983) Xylem Structure and the Ascent of Sap. Springer-Verlag, Berlin-Heidelberg, New York, Tokyo.

[36] Dean, J.F.D. (1997) Lignin Analysis. In: Dashek, W.V., Ed., Methods in Plant Biochemistry and Molecular Biology, CRC Press, Boca Raton, 199-215.

[37] Blakeney, A.B. and Matheson, N.K. (1984) Some Properties of the Stem and Pollen Starches of Rice. Starch-Stärke, 36, 265-269. http://dx.doi.org/10.1002/star.19840360803

[38] Morita, S. and Collins, H.P. (1990) A Method to Describe Root Branching. Japanese Journal of Crop Science, 59, 580-581. http://dx.doi.org/10.1626/jcs.59.580

[39] McCully, M.E. (1995) How Do Real Roots Work? Some New Views of Root Structure. Plant Physiology, 109, 1-6.

[40] Shiotsu, F., Abe, J., Ra, K., Gau, M. and Morita, S. (2011) Root Distribution of Perennial Energy Crop Erianthus. 7th International Symposium on Structure and Function of Roots, Nový Smokovec, Slovakia, 5-9 September 2011, 160161.

[41] Kato, Y., Kamoshita, A. and Yamagishi, J. (2007) Evaluating the Resistance of Six Rice Cultivars to Drought: Restriction of Deep Rooting and the Use of Raised Beds. Plant and Soil, 300, 149-161. http://dx.doi.org/10.1007/s11104-007-9397-z

[42] Abe, J. and Morita, S. (1994) Growth Direction of Nodal Roots in Rice: Its Variation and Contribution to Root System Formation. Plant and Soil, 165, 333-337. http://dx.doi.org/10.1007/BF00008078

[43] Kaeriyama, N. and Yamazaki, K. (1983) The Development of Rooting Zone in Soil in Relation to the Growth Direction and the Elongation Rate of the Primary Roots in Corn Plants. Japanese Journal of Crop Science, 52, 508-514. http://dx.doi.org/10.1626/jcs.52.508

[44] Kondo, M., Aragones, D.V., Pablico, P.P., Murty, M.V.R., Okada, K., Abe, J. and Morita, S. (1999) Approaches in Plant-Soil Interaction to Improve Upland Rice Production. In: Horie, T., Geng, S., Amano, T., Inamura, T. and Shiraiwa, T., Eds., World Food Security and Crop Production Technologies for Tomorrow, JSCS, Kyoto, 221-224.

[45] Botwright-Acuna, T.L., Pasuquin, E. and Wade, L.J. (2007) Genotypic Differences in Root Penetration Ability of Wheat through Thin Wax Layers in Contrasting Water Regimes and in the Field. Plant and Soil, 301, 135-149. http://dx.doi.org/10.1007/s11104-007-9428-9

[46] Yu, L.X., Ray, J.D., O’Toole, J.C. and Nguyen, H.T. (1995) Use of Wax-Petrolatum Layers for Screening Rice Root Penetration. Crop Science, 35, 684-687. http://dx.doi.org/10.2135/cropsci1995.0011183X003500030005x

[47] Yamazaki, K. and Kaeriyama, N. (1982) The Morphological Characters and the Growing Directions of Primary Roots of Corn Plants. Japanese Journal of Crop Science, 51, 584-590. http://dx.doi.org/10.1626/jcs.51.584

[48] Materechera, S.A., Dexter, A.R. and Alston, A.M. (1991) Penetration of Very Strong Soils by Seedling Roots of Different Plant Species. Plant and Soil, 135, 31-41. http://dx.doi.org/10.1007/BF00014776 
[49] Zheng, H., Babu, R.C., Pathan, M.M.S., Ali, L., Huang, N., Courtois, B. and Nguyen, H.T. (2000) Quantitative Trait Loci for Root-Penetration Ability and Root Thickness in Rice: Comparison of Genetic Backgrounds. Genome, 43, 53-61. http://dx.doi.org/10.1139/g99-065

[50] Stamp, P. and Kiel, C. (1992) Root Morphology of Maize and Its Relationship to Root Lodging. Journal of Agronomy and Crop Science, 168, 113-118. http://dx.doi.org/10.1111/j.1439-037X.1992.tb00987.x

[51] Morita, S. and Okuda, H. (1995) Elongation and Branching of Seminal and Nodal Roots in Wheat Grown under Field Condition. Japanese Journal of Crop Science, 64, 14-18. http://dx.doi.org/10.1626/jcs.64.14

[52] Morita, S., Thongpae, S., Abe, J., Nakamoto, T. and Yamazaki, K. (1992) Root Branching in Maize: I. "Branching Index” and Methods for Measuring Root Length. Japanese Journal of Crop Science, 61, 101-106. http://dx.doi.org/10.1626/jcs.61.101

[53] Kawata, S., Yamazaki, K., Ishihara, K., Shibayama, H. and Lai, K. (1964) Studies on Root System Formation in Rice Plants in a Paddy. Japanese Journal of Crop Science, 32, 163-180. http://dx.doi.org/10.1626/jcs.32.163

[54] Ješko, T. (1989) Root-Shoot Relationships in Sorghum and Maize Plants with Different Numbers of Seminal Adventitious Roots. In: Loughamn, B.C., Gašparikova, O. and Kolek, J., Eds., Structural and Functional Aspects of Transport in Roots, Kluwer Academic Publishers, Dordrecht, 189-193.

[55] Nagano, T., Ishida, T. and Morita, S. (1993) Internal Plant-Water-Status and Its Control (4). Resistances to Water Flow through Some Root Systems. Environment Control in Biology, 31, 147-153. http://dx.doi.org/10.2525/ecb1963.31.147

[56] Heimsch, C., Rabideau, G.S. and Whaley, W.G. (1950) Vascular Development and Differentiation in Two Maize Inbreds and Their Hybrid. American Journal of Botany, 37, 84-93. http://www.jstor.org/stable/2437960

[57] Mani, A.P. (1963) Size-Structure Correlation in the Vascular System of Roots in Cyperus. Science and Culture, 29, 357-358.

[58] Morita, S. and Nemoto, K. (1995) Morphology and Anatomy of Rice Roots with Special Reference to Coordination in Organo- and Histogenesis. In: Baluška, F., Ciamporová, M., Gašparíková, O. and Barlow, P.W., Eds., Structure and Function of Roots, Kluwer Academic Publishers, Dordrecht, 75-86.

[59] Vermeer, J. and McCully, M.E. (1982) The Rhizosphere in Zea: New Insight into Its Structure and Development. Planta, 156, 45-61. http://dx.doi.org/10.1007/BF00393442

[60] Nambiar, E.K.S. (1976) The Uptake of Zinc-65 by Oats in Relation to Soil Water Content and Root Growth. Australian Journal of Soil Research, 14, 67-74. http://dx.doi.org/10.1071/SR9760067

[61] Enstone, D.E., Peterson, C.A. and Ma, F. (2003) Root Endodermis and Exodermis: Structure, Function, and Responses to the Environment. Journal of Plant Growth Regulation, 21, 335-351. http://dx.doi.org/10.1007/s00344-003-0002-2

[62] Kawata, S., Sasaki, O. and Yamazaki, K. (1977) On the Structure of the Crown Root and the Lateral Root, and the Vessel Connection between Them, in Rice Plants. Japanese Journal of Crop Science, 46, 569-579. http://dx.doi.org/10.1626/jcs.46.569

[63] Morita, S. and Abe, J. (1999) Perspective of Root Research. Japanese Journal of Crop Science, 68, 453-462. http://dx.doi.org/10.1626/jcs.68.453

[64] Galamay, T.O., Yamauchi, A., Tatsumi, J. and Kono, Y. (1992) Cortical Sclerencyma Development in Axile Roots of Cereal Crops. Japanese Journal of Crop Science, 61, 494-502. http://dx.doi.org/10.1626/jcs.61.494

[65] Kondo, M., Aguilar, A., Abe, J. and Morita, S. (2000) Anatomy of Nodal Roots in Tropical Upland and Lowland Rice Varieties. Plant Production Science, 3, 437-445. http://dx.doi.org/10.1626/pps.3.437

[66] Raechal, L.J. and Curtis, J.D. (1990) Root Anatomy of the Bambusoideae (Poaceae). American Journal of Botany, 77, 475-482. http://www.jstor.org/stable/2444381

[67] Yamashita, M. and Okamoto, A. (2008) Seasonal Variation in Rooting Potential of Kureme Azalea "Chikushibeni” (Rhododendron Kurume Group). Plant Root, 2, 54-57. http://dx.doi.org/10.3117/plantroot.2.54 
Scientific Research Publishing (SCIRP) is one of the largest Open Access journal publishers. It is currently publishing more than 200 open access, online, peer-reviewed journals covering a wide range of academic disciplines. SCIRP serves the worldwide academic communities and contributes to the progress and application of science with its publication.

Other selected journals from SCIRP are listed as below. Submit your manuscript to us via either submit@scirp.org or Online Submission Portal.
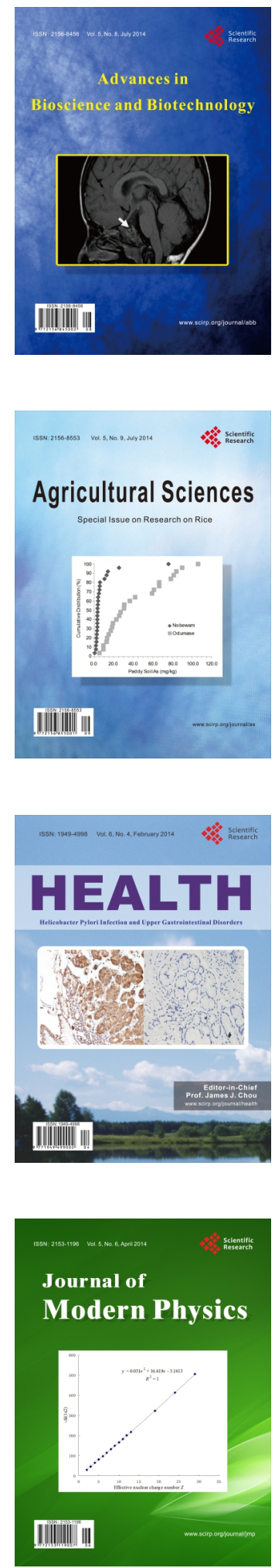
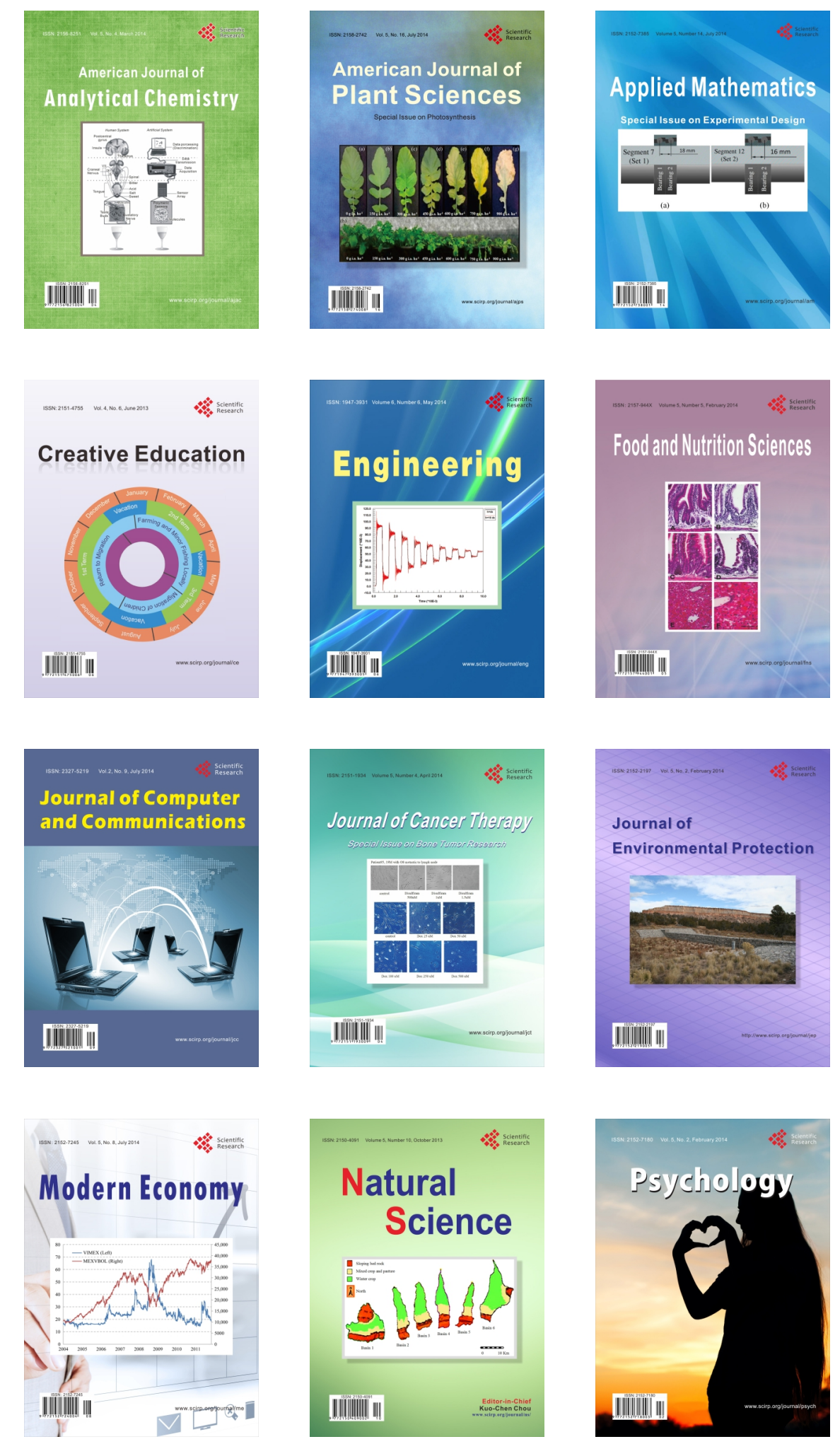